his is an Accepted Manuscript of an article published by Taylor \& Francis in The Pacific Review on 15 Aug 2019, available online: http://www.tandfonline.com/10.1080/09512748.2019.1651384

Accepted version downloaded from SOAS Research Online: http://eprints.soas.ac.uk/31413

\title{
How China Views North Korea's Readiness to Reform and Its Influence on China's \\ North Korea Policy in the Post-Cold War Era*
}

(July 2019)

\author{
10,940 words (main text) \\ 188 words (abstract)
}

Tat Yan Kong PhD

Reader (Associate Professor) in Comparative Politics \& Political Economy

Department of Politics \& International Studies

SOAS, University of London

Thornhaugh Street

London WC1H 0XG

yk2@soas.ac.uk

Tel. 44+(0)20-7898-4743 
Tat Yan Kong is Reader (Associate Professor) in Comparative Politics and Political Economy at SOAS, University of London, and Co-Director of the London Asia-Pacific Centre for Social Science (SOAS and King's College London). He is interested in issues of comparative and international political economy (varieties of capitalism, socialist to market transition, regional integration) with reference to East Asia (and to the Korean Peninsula in particular) and is the author The Politics of Economic Reform in South Korea: A Fragile Miracle (London and New York: Routledge, 2000). His other publications include articles in journals such as British Journal of Political Science, Economy \& Society, Modern Asian Studies, New Political Economy, The Pacific Review, Political Studies, Politics \& Society and Review of International Political Economy. 


\title{
How China Views North Korea's Readiness to Reform and Its Influence on China's North Korea Policy in the Post-Cold War Era ${ }^{1}$
}

\author{
Tat Yan Kong
}

\begin{abstract}
China's policy of restraint (avoidance of crippling economic sanctions) towards North Korean provocation is typically explained in terms of geopolitical concern with North Korean regime stability. The strategic and diplomatic costs of restraint would suggest the presence of non-geopolitical influences behind China's approach. Ideational explanations emphasise the persistence of shared socialist identity as well as the traditional Sino-centric worldview as shaping influences. There is much less detailed analysis of how China views North Korea's political economic evolution and how this view has changed over time to produce fluctuations in the bilateral relationship. In order to capture China's motivations more fully, I introduce two additional variables, namely China's view of the state its own reform path (which provides the domestic context shaping policy towards North Korea), and the extent of North Korea's readiness to prioritise economic reform. I will then use these variables to explain two contrasting phases which represented the worst (1992-9) and best (2009-12) of times of the bilateral relationship in the post-Cold War era. These variables also help us to understand the potentials and limitations of the upturn in bilateral relations which has occurred since 2018 .
\end{abstract}

Key words: China-North Korea relations; 'economy first'; mono transition; monolithic leadership system; 'parallel advance'; socialist identity 


\section{The puzzle of China's restrained approach towards North Korea}

North Korea's WMD² programme has posed a threat to East Asian security since the early 1990s. ${ }^{3}$ Accelerated development since 2016 and the danger of direct military conflict with the US under the Trump administration highlighted the role of China ${ }^{4}$ as North Korea's sole economic and diplomatic lifeline. The puzzle arises as to why has China exercised restraint towards North Korea despite the disadvantages of doing so. This article argues that the existing geopolitical and ideational explanations cannot fully explain the policy of restraint or other fluctuations in China's policy towards North Korea in the post-Cold War era. To fully capture China's motivations, they need to be supplemented by two further variables. The first variable is China's view of the state of its own reform path (which provides the domestic context of policy towards North Korea). The second variable shaping China's policy is North Korea's ordering of economic versus non-economic priorities.

\section{China's restrained approach towards North Korean provocation}

In spite of North Korea's acceleration of WMD development under the Kim Chŏng-Ŭn regime (2012-present), China continued to adhere to an approach encapsulated in the three principles of 'denuclearisation', 'peace and stability' and 'dialogue and negotiation' (Ministry of Foreign Affairs 2009) enunciated in the 2000s. In practice, this approach meant the reliance on even-handed diplomacy reinforced by moderated sanctions. Even-handed diplomacy meant respect for North Korea's interests while moderated sanctions meant the ratcheting up of economic sanctions that would slow but not cripple North Korea's economy. 
In effect, it represented an approach to denuclearisation that ruled out measures that could result in war or North Korean regime collapse.

In the application of economic sanctions, China supported UN sanctions since the first nuclear test of 2006 (Arms Control Association 2018), ${ }^{5}$ but it also insisted on respect for North Korea's 'national development' (a euphemism for social stability). In opposition to North Korea's nuclear provocations, China sought to inflict economic pain rather than induce economic collapse. For example, North Korea's third nuclear test of 2013 was met with China's suspension of the ambitious infrastructural projects agreed in the preceding period of good relations (2009-12) and some financial restrictions, but private trade was permitted to flourish. These measures of the new Xi Jinping administration were acclaimed as a 'dramatic policy transformation' that contrasted with the 'appeasing-style' of 2003-10 (Shi 2015: 26-7) but Figure 1 reveals continuously rising level of China-North Korea trade through the 200616 sanctions decade. The rising bilateral trade level was indicative of the continuous improvement of North Korea's economic condition, and by extension, its capacity to sustain the WMD programme. In effect, China was taking the sting out of international sanctions. In response to further escalation in 2016-17, China supported 'unprecedented' UNSC sanctions that resulted in the suspension of imported coal, iron ore and textiles as well as the partial suspension of oil exports. By the end of 2017, China had fostered a very high degree of North Korean dependency, accounting for USD 5.25 billion or 94.7 per cent of North Korea's total trade of USD 5.55 billion. Nevertheless, China refrained from fully utilising its leverage by complete suspension of oil exports and tight closure of the border.

Figure 1 about here 
China has pursued diplomatic resolution alongside the incremental tightening of economic sanctions. In response to North Korea's accelerated nuclear testing in 2016, China continued to display diplomatic even-handedness in terms of sensitivity to North Korea's security and diplomatic concerns by pointing out US military threat and direct negotiation with the US. While the Six Party Talks ${ }^{6}$ for denuclearisation had stalled as a result of North Korea's withdrawal in 2009, China attempted to resurrect multilateral forum during the 2010s while combining it with other initiatives. This approach was most clearly manifested in China's call for 'dual suspension' with 'dual track' negotiations at the lowest point of the crisis in 2017. 'Dual suspension' of North Korean WMD tests and joint US-South Korean military exercises would provide a favourable environment for multilateral denuclearisation talks and bilateral US-North Korea normalisation talks (Fu 2017: 23).

Diplomatic even-handedness was also evident from the persistence of Chinese high-level contact with North Korea. Despite the worsening of the nuclear crisis, Beijing sought to avoid the diplomatic isolation of Pyŏngyang. A recent dataset revealed that the mean number of China-North Korea high-level visits per year during the 2012-17 period of nuclear tension was not the lowest recorded in the history of the relationship (Cha and Lim 2017). Prior to the Xi Jinping-Kim Chŏng-Ǔn summit meeting of March 2018, there occurred senior-level exchange at both party and state-levels. ${ }^{7}$ Chairman Kim Chŏng-Ŭn chose Beijing as the destination for his maiden overseas trip as Supreme Leader (25-27 March 2018). The historical pattern of relations (since the 1950s) suggests that rifts, however serious, are followed by renewed cooperation as both sides reaffirm their 'shared heritage'. The five summit meetings between $\mathrm{Xi}$ and $\mathrm{Kim}$ in 2018-19 conform to this pattern. 


\section{The costs of restraint}

China has paid a price for not using its full economic leverage against North Korea. It has been seen as North Korea's enabler. North Korea's trouble making justified the very US military containment measures that China had sought to avoid. In particular, South Korea perceived China's response to North Korea's fourth nuclear test of January 2016 to be inadequate and decided to deploy THAAD (an advanced US anti-ballistic missile system) in July 2016. Perceiving a strategic threat, China conducted economic retaliation against South Korea, its second biggest trading partner at the time. ${ }^{8}$ Beijing had designated South Korea as a 'fulcrum state' in its neighbourhood diplomacy (Wu 2018: 862) but retaliation for THAAD retaliation undermined the careful courtship of the Park Geun-Hye administration. Instead it reinforced Seoul's cooperation with Washington. Moreover, under the new Trump administration's policy of 'maximum pressure with engagement' towards North Korea in 2017, the US targeted Chinese economic entities with 'secondary sanctions' (Hangyoreh 1 July 2017). These North Korea-related secondary sanctions also fed into the Trump administration 'maximum pressure' campaign against China in the pursuit of trade rebalancing, a campaign that also included tariffs and advanced arms sales to Japan, South Korea and Taiwan.

The policy of restraint appeared to be at variance with the critical view of North Korea that prevailed among a growing number of Chinese policy scholars and commentators. Since the mid-2000s, such 'strategists' have criticised the 'traditionalist' view of North Korea as a strategic asset created with enormous blood sacrifice. Instead, they viewed it as a strategic liability of limited military value in the age of modern warfare and detrimental to the crucial relationship with the US (Kim 2010: 59-63). These critical voices were increasingly reflected 
among well-known scholars and commentators using both foreign and domestic outlets. Given China's system of media control, publication in domestic outlets always reflects some degree of official tolerance. An example of an open source associated with the government is World Affairs, a journal sponsored by the Ministry of Foreign Affairs (MOFA). This journal regularly gave space to Zhang Liangui, a professor at the Central Party School and vocal critic of North Korea. Zhang viewed nuclear possession as the inevitable product of North Korea's nationalist state ideology of chuch'e ('national autonomy') (Zhang 2009). He also cast doubt on the economic opening of 2009-10, suspecting a ploy to secure more resources for military use while stirring up China-US tensions (Zhang 2011).

Despite the official policy of restraint, the tone of Chinese commentary about North Korea became increasingly harsh during the 2010 s, especially after the third nuclear test of February 2013. The prominent case of Deng Yuwen, who was dismissed from his official post as Deputy Editor of the Central Party School's theoretical journal Study Times for his Financial Times article of 2013, appears to be the exception to the trend. In the article, Deng claimed North Korea's nuclear weapons posed a direct threat to North Korea and called on the Chinese government to abandon its support for the ruling Kim family (Deng 27 February 2013). This sentiment was subsequently echoed by well-known Chinese scholars writing in external outlets. For example, the Cold War historian Shen Zhihua stated that 'Beijing should cooperate with Washington ... and prepare for the eventual meltdown of the DPRK' (Shen and Xia 2015: 104). In the same volume, Zhu Feng, then an IR professor at Peking University, asked whether 'President $\mathrm{Xi}$ and his team can proactively resolve to dump the unnecessary burden of a Kim-controlled North Korea' (Zhu and Beauchamp-Mustafaga 2015: 56). 
With the worsening of the crisis in 2016-17, prominent scholars further questioned the wisdom of official policy and articulated more controversial policy recommendations. For example, at a lecture in March 2017, Shen Zhihua harshly criticised Beijing's decision to pressure South Korea economically over THAAD as being devoid of foreign policy sense. For Shen, both South Korea and China were victims of the US-North Korea spiral of conflict initiated by P'yŏngyang's nuclearisation. As such, he identified North Korea as China's 'latent enemy’ while South Korea was a potential friend (Shen 2017). Similar sentiments were echoed by Jia Qingguo, a professor and Director of the Institute of International Studies at Peking University and member of Standing Committee of the Chinese People's Political Consultative Conference or CPPCC (functionally a type of legislative upper house). Jia (2016) questioned the Chinese government's reaction to South Korea's THAAD deployment given that North Korea was the root (genzi) of the problem. He also recommended stronger sanctions including cessation of oil exports, and close coordination with the US regarding possible conflict scenarios and outcomes including the fate of the Peninsula post-North Korea (Jia 2017). While tolerating more diverse viewpoints, the Chinese authorities did not waver from its line of restraint.

\section{Explaining the puzzle: geopolitical and ideational explanations}

Given the diplomatic and strategic costs incurred, China's restraint towards North Korea in the face of discordant policy voices is a puzzle of both academic and policy interest. The geopolitical answer as to why China showed a restrained policy towards North Korea focuses on the strategic costs and benefits. Zhu and Beauchamp-Mustafaga (2015: 44-5, 51-2) put this argument very succinctly. They argue that Chinese policy makers are motivated 
primarily by security considerations in their dealings with North Korea and from that angle, they perceive that the strategic positives outweigh the negatives, whereas western accounts normally emphasise the negatives. This strategic assessment is heavily conditioned by considerations of the strategic rivalry with the US. The positives include the continuing existence of a buffer zone of non-US presence and Chinese influence over North Korea as a potential bargaining chip with the US. This would fit with the result of a survey of Chinese international relations scholarship that found few policy scholars regarded the Korean Peninsula as a Chinese 'core interest' (1.85 per cent of articles) whereas most viewed the US as the major threat to 'core interests' (56.4 per cent) (Zeng, Xiao and Breslin 2015: 261, 263). The US was perceived not only as a direct military threat but also to be insidiously manoeuvring China towards a costly confrontation with a nuclear armed North Korea. As the Global Times (20 February 2016) stated in the aftermath of the fourth nuclear test:

The US does not want North Korea to have nuclear weapons. But if the Peninsula becomes peaceful, the US may be worried that the allied South will walk away and embrace the North. The US would be happier to see China become a major foe of North Korea so the Korean Peninsula troubles will shift to China. The North Korean issue has become an excuse for the US to prepare for the rise of China ... P'yŏngyang made a mistake in its first step of developing nuclear weapons. Now the nuclear issue has been pulling China deeper into the mire

By the beginning of 2017, however, the strategic positives were becoming far less apparent. P'yŏngyang paid little heed to Beijing in the escalating confrontation with the new Trump administration. Breaking with its predecessor's doctrine of 'strategic patience', the new administration's 'maximum pressure with engagement' strategy included President Trump's 
threat to 'totally destroy North Korea' (18 September 2017) and intensified secondary sanctions against Chinese economic entities. Prominent Chinese scholars also called for stronger measures against North Korea (see above). These escalating strategic and diplomatic costs of restraint would suggest the presence of ideational influences behind China's restrained approach. Ideational explanations emphasise the tension between China's emerging sense of being a 'responsible great power' abiding by international norms (e.g. nonproliferation) on the one hand, and more established outlooks based on socialist solidarity or Sino-centric tributary relations, on the other.

In the view of Noesselt (2014), China's North Korea policy is shaped by competing 'national role conceptions' as both responsible global leader and socialist power. Despite economic modernisation, China continues to define itself as a socialist power but of a new type distinct from both defunct Soviet state socialism and liberal-democratic capitalism. It is clearly distinguished from the latter by its continuing adherence to one-party rule (Noesselt 2014: 1312). Sharing the core value of one-party rule, Beijing cannot renounce P'yŏngyang's 'socialism' without questioning its own. Since China accepts North Korea's socialist credentials, the party-to-party relationship survives despite periodic ups and downs. When North Korea creates military tension, this socialist dimension of 'national role conception' comes into tension with the emerging dimension of China as a 'responsible great power' that upholds international norms (Noesselt 2014: 1313).

Easley and Park (2016) locate North Korea in China's 'near abroad' where the traditional (i.e. Imperial-era) Sino-centric world view prevails over international norms. That world view is built on the norms of stability, siege mentality, expectation of deference and Confucian reciprocity. 'Stability' means preventing the emergence of national security 
threats. 'Siege mentality' means preventing encirclement. 'Stability' and 'siege mentality' resemble the standard geopolitical concern with North Korea as a special 'buffer state'. 'Expectation of deference' means North Korea should recognise its junior status and embrace Chinese practices. 'Confucian reciprocity' means expectation of Korean respect for mutual obligations inherent in the hierarchical relationship (especially loyalty in exchange for protection) (Easley and Park 2016: 657-60). They apply these norms to explain China's responses to North Korea's first three nuclear tests. China introduced sanctions when North Korea showed disrespect by conducting its first nuclear test of October 2006 ('deference') but the severity of punitive sanctions was qualified by the norms of 'stability' (avoid North Korea's collapse) and 'siege mentality' (not forcing North Korea into a violent reaction). After the second nuclear test of May 2009, however, 'stability' and 'siege mentality' took precedence over 'deference' given China's concerns about North Korea's domestic stability (facing leadership succession) and the hostile state of inter-Korean relations. In response, China took active steps to bolster North Korea both diplomatically and economically. The toughening of China's attitude (condemnation, stronger sanctions) after North Korea's third nuclear test of February 2013 is explained by P'yŏngyang's failure to show restraint after having received the diplomatic and economic benefits from Beijing (violation of the 'reciprocity’ norm) (Easley and Park 2016: 660-6).

\section{Capturing the missing dimensions}

These alternative ideational accounts usefully highlight some constant motivations underlying China's policy towards North Korea, namely, China identifies North Korea as a fellow socialist regime but also as a junior neighbour that should follow Chinese guidance. 
However, they cannot fully explain China's two most important policy shifts towards North Korea in the post-Cold War era. The first shift produced the low point in relations (1992-9) when Chinese economic pressure contributed to economic collapse. The shift towards economic engagement produced the high point (2009-12) in the bilateral relationship. Chinese resources provided the basis for economic recovery and stable hereditary succession in the 2010s. If we take the low point, Noesselt's emphasis on the constancy of shared socialist identity cannot explain why China chose to pressure its ally economically during the early 1990s (by terminating trade subsidies). North Korea had only recently demonstrated its solidarity by backing the Chinese authorities over the Tiananmen Square crisis of 1989. In other words, P'yŏngyang had reaffirmed the shared socialist identity when Beijing most needed it. Such solidarity would also satisfy the norms of 'deference' and 'reciprocity' identified by Easley and Park. Their norms of 'stability' and 'siege mentality', like the standard geopolitical explanations, would also have dictated that China keep North Korea close instead of exacerbating its economic woes (since these woes accelerated North Korea's nuclear programme to China's detriment).

Existing accounts cannot fully explain the recent high point (2009-12) in relations either. Like the standard geopolitical accounts, Easley and Park emphasise that the traditional norms of 'stability' and 'siege mentality' reasserted themselves in Chinese policy owing to fear of inducing North Korean regime collapse. If anything, North Korean actions (permanent withdrawal from the Six Party Talks and second nuclear test) demonstrated unity of purpose and enhanced material power rather than fragility. Moreover, similar considerations did not prevent China from tightly squeezing a much weaker North Korea during the early 1990s. The intensification of economic engagement with North Korea in 2009 is also difficult to explain from Noesselt's account, based on China's recognition of North Korea as a fellow 
socialist regime. In its provocative behaviour during the first half of 2009, North Korea displayed little consideration for Chinese interests. Socialist solidarity, therefore, cannot account for China's decision to ramp up its economic support to North Korea in the second half of 2009. These accounts overlook Beijing's appreciation of the subtle systemic changes taking place beneath P'yŏngyang's provocative exterior. Apart from the calculations about regime stability or the constancy of shared socialist identity, another important factor for consideration is China's assessment of North Korea's potential for reform (i.e. its readiness to assimilate Chinese-type practices). In the early 1990s, North Korea was considered very rigid by the Chinese side (and economically pressured towards change). In the late 2000s, by contrast, after a decade of informal marketisation and commercialised trade with China, there was more potential for successfully transplanting Chinese-style reform by deeper economic engagement.

To capture more fully the effect of this economic dimension behind the fluctuations in Chinese policy, I introduce two additional variables for analysis. I begin from the premise that China seeks to transplant its own reformist practices to North Korea. This premise conforms with the existing explanations of Chinese policy be they geopolitical (enabling a 'soft landing' from the economic crisis) or ideational (viewing North Korea as a junior socialist ally or latter-day vassal state bound by traditional ties). Building on this premise, the first variable is how China views the progress of its own reform path or the vantage point from which China views North Korea. This provides the domestic context of policy towards North Korea. In the early 1990s, China had become a reform laggard, having been overtaken in economic reform by the new post-socialist economies. In order to regain its reform momentum, it started to assimilate the economic tools of neo-liberalism more eagerly in tandem with stricter authoritarianism. Against this background, Beijing came to view 
P'yŏngyang's economic rigidity and aid dependency in an unfavourable light. Adding this context enables us to better understand why China chose to apply a strong dose of economic pressure to induce its neighbour to reform. By the late 2000s, however, China was no longer playing catch-up with the post-socialist economies. Instead, it had established itself as a reform leader in terms of both managing continuous systemic transition and promoting national development while maintaining one-party rule. Rather than eagerly emulating economic neo-liberalism, it was now confidently transplanting aspects of its own experience to developing countries by aid and investment. In terms of North Korea policy, this was manifested in an incentive-based approach that displayed greater sensitivity towards North Korea's reform constraints.

The second variable shaping China's policy is North Korea's ordering of economic versus non-economic priorities. Economic priority in the post-Cold War era means the acceptance and active support for gradual marketisation. Non-economic priorities are denoted by nonproductive activities, notably prestige projects for bolstering monolithic rule and worse, development of WMDs. Given China's interest in transferring its brand of reformist economics in the post-Cold War era, it has strongly favoured North Korean prioritisation of economic development. The more North Korea can demonstrate economic reform orientation, the more China is inclined to support it. Our framework applies primarily to the post-Cold War era because the leitmotif of Chinese policy was very different during the Cold War (using material incentive to secure North Korean support in the Sino-Soviet dispute). Economic reform was not a powerful factor shaping China's view of North Korea. The interaction of the two variables can be mapped as in Figure 2.

Figure 2 about here 
When China was eagerly assimilating the economic tools of neoliberalism, the domestic impulse to accelerate reform also translated into pressure towards unreconstructed North Korea (1992-9), resulting in frozen relations. By contrast, having become an exemplar of systemic reform and national development that was distinct from liberal capitalism, China was ready to transplant its own experience by material input to a North Korea that was also seeking a path of economic reform (2009-12), resulting in friendly relations. The current period (since 2018) may also be seen in this light. By contrast, when North Korea appeared to retreat from reform by co-prioritising WMD development under the slogan of pyŏngjin nosŏn or 'line of parallel advance' (from 2013), China applied increasing (but not crippling) pressure resulting in lukewarm relations (but not frozen as in the 1990s). There is a long period of improving relations (1999-2009) during which China transformed from reform laggard to reform leader (especially from 2004) and North Korea gradually adapted to informal markets and expanded its commercial trade. During this period, China encouraged commercial trade with North Korea but did not take the pro-active steps characteristic of the 2009-12 period.

To highlight the interaction of the variables, I will use them to examine the low (1992-9) and high (2009-12) points of the bilateral relationship. During these critical episodes, North Korea experienced deep economic crisis (1992-9) and economic recovery (2009-12). The latter provided the material basis for the successful continuation of hereditary rule into the third generation. They also illustrate the extent (and limitations) of China's influence. As to which sources can be considered representative of China's changing perception towards North Korea, the official position is represented by statements from the Ministry of Foreign Affairs (MOFA) and by articles from official outlets such as People's Daily, Beijing Review, 
China Daily and Global Times. All four of these sources reflect the views of the Chinese Communist Party (CCP). For greater depth, I also examine a range of expert analyses that have become permissible in Chinese open sources. In particular, I make use of World Affairs, a journal sponsored by the MOFA whose remit includes 'to propagate the foreign relations directions, policies and strategies of the party and government and to use the Marxist perspective to analyse the changing international situation and trend of development' (World Affairs Editorial Office).

\section{The low point (1992-9)}

This was the longest period without a summit meeting between the two sides. ${ }^{9}$ Grateful for North Korean solidarity during the Tiananmen Square crisis of 1989, China's leadership made a symbolic show of solidarity. For example, Jiang Zemin visited P'yŏngyang in March 1990 on his maiden foreign trip as General Secretary. Nevertheless, China followed the USSR in pursuing diplomatic normalisation with South Korea. By supporting the dual entry of both Koreas into the United Nations in 1991, China had already renounced its traditional policy of recognising only the North. Nor was Beijing prepared to wait for P'yŏngyang to normalise relations with Tokyo. Nevertheless, China continued to pledge friendship and material support and several top Chinese leaders visited P'yŏngyang (Lee 1996: 127). Despite its friendly exterior, China did not make good on its material promises even though North Korea was reeling from the termination of Soviet subsidy in 1990. Disregarding previous guarantees, China also decided to abolish the 'friendship pricing' of oil exports in 1991 (with a two-year transition period). The following year, China stipulated that trade would be conducted in hard currency at international prices (Lee 1996: 140). Chinese grain 
shipments to North Korea plummeted in 1994 as a consequence, a factor that directly contributed to North Korea's dire food shortages of the 1990s (Eberstadt 1998: 203-30). These reverses spurred North Korea into accelerated nuclear development in a gamble to ensure security and lure the US into direct talks. The onset of famine in 1996 forced China to provide substantial emergency aid, but this did not earn any gratitude from the North Koreans (Kim 2001: 386-7).

\section{The domestic context: China eagerly assimilates neoliberal economic tools}

Difficult to understand from the perspectives of geopolitics or socialist solidarity, China's harsher economic policy towards North Korea becomes clearer if one appreciates the context of the Chinese regime's thinking about how its own political economic system should adapt to the post-Cold War environment. Following the twin shocks of the Tiananmen Square crisis and Soviet bloc collapse, the future of China's mono transition strategy (cautious market reform within the one-party system) appeared to be in doubt. Having previously led the socialist world in economic reform, post-Cold War China now appeared to lag behind the new post-socialist states of Eastern Europe and Russia. While rejecting their rapid liberalisation ('big bang') approach, China eventually introduced its own 'mini bang' to enhance market orientation at the micro-level (Fu 1995). The 'deepening of neo-liberal capitalism' meant faster, and more socially painful, market reform measures while maintaining tight political control (So and Chu 2012: 174-7). According to General Secretary Jiang Zemin (Jiang 1991: 21): 
We should continue to allow some people and some regions to prosper before others through honest labour and lawful operations while also encouraging those who prosper to help those who are still left behind

The restoration of political order and temporary economic adjustment of 1989-90 provided the basis for a reinvigorated mono transition strategy. Premier Li Peng described this as 'the relationship between reform, development and stability' (Li 1991: 12). In support of reinvigorated reform, paramount leader Deng Xiaoping undertook his famous Southern Tour of the most economically dynamic regions in the spring of 1992 . At its $14^{\text {th }}$ Congress later that year, the CCP replaced 'socialism with Chinese characteristics' with 'socialist market economy', a designation that placed market principles and institutions at the centre of economic governance (Wu 2009: 41).

Alongside economics, there were developments in the sphere of official political ideology. To accommodate the simultaneous demands of economic prosperity and political stability, Chinese scholars began to advance the concept of 'neo-authoritarianism' from the mid-1980s as the substitute for Maoist or totalitarian governance. They drew their inspiration from conservative modernisation theory (notably from Samuel Huntington) that stressed the need for centralised power with institutionalised participation during times of rapid transformation (Li 2015). The exemplary cases were represented by the recent authoritarian capitalist developmental regimes of South Korea and Taiwan (c. 1960-87) (Klein 2010: 10). The top leaders of the CCP (including reformist General Secretary Zhao Ziyang and conservative paramount leader Deng Xiaoping) were reported to be favourably inclined towards the neoauthoritarian formulation (Sautman 1992: 89). Following the 'neo-authoritarian' logic, China's post-Tiananmen leaders emphasised 'reform and opening' under the guidance of the 
'four cardinal principles' (i.e. commitment to socialism; leading role of the CCP; people's democratic dictatorship; and Marxism-Leninism Mao Zedong Thought), which stood in opposition to ‘bourgeois liberalisation' or liberal democratisation (Jiang 1991: 26). Like the earlier developmental authoritarianisms of East Asia, China also enthusiastically welcomed foreign capital. An official piece attacking 'bourgeois liberalisation' made this important distinction:

Opposition to such 'liberalisation' in China has nothing to do with the capitalist system in other countries. And it is not in the least designed to stop economic and technical exchanges with the Western countries or to keep foreign capitalists from investing in China (An 1990: 16)

\section{Effect on policy towards North Korea}

These internal developments influenced China's policy towards North Korea. From the launch of 'reform and opening' in 1978, China had looked unfavourably upon Kim Il-Sŏng's personality cult and plans for hereditary succession. For example, in 1980, the People's Daily even criticised the hereditary succession as feudal practice (Isozaki 2017: 33). When the Chinese leadership finally acquiesced to the hereditary succession, it believed it had secured Kim Il-Sŏng's reciprocal commitment to economic reform. On his frequent visits, Chinese hosts repeatedly showed Kim the practical benefits of economic reform. However, North Korean emulation was very superficial. When Kim Chŏng-Il visited China in 1982, he promised to return regularly to study Chinese-style economic reform but he did so only once (in 1983) before 2001. In 1984, North Korea copied China's foreign direct investment law 
but did not introduce any practical facilitating measures (e.g. development of supporting infrastructures or institutions that would ease foreign investment). The main impediment was ideological. Kim Chŏng-Il's status as hereditary successor was legitimised by his faithful allegiance to the achievements of Kim Il-Sŏng (S.C. Kim 2010: 128-9). Consequently, North Korea chose the tested path of exploiting the old Sino-Soviet divide. After receiving improved terms of concessional trade from the USSR in 1984 and 1986, North Korean interest in Chinese-style reform diminished (Oberdorfer 1999: 202).

Against the background of domestic change and ideological self-examination, the sympathies of Chinese policy makers and scholars began to shift away from North Korea. Despite claims of 'non-interference' in the domestic affairs of other states, Beijing was becoming more insistent on P'yŏngyang mending its ways. For example, in October 1991, Kim Il-Sŏng visited China (his $39^{\text {th }}$ and final trip) seeking economic aid and delay to the impending normalisation of China-South Korea relations. Beneath the lavish welcome (received at the train station by the CCP General Secretary, Prime Minister, and State President), Chinese leaders lectured Kim on the necessity of economic reform. Premier Li Peng reportedly informed Kim about a recent decision to reform inefficient state-owned enterprises (Korea Times 6 October 1991). Much of Kim's unusually long 10-day visit was spent visiting Chinese industrial facilities (Korea Times 8 October 1991). The high-level send-off was not accompanied by any joint communiqué (Korea Times 13 October 1991). Following North Korea's fierce criticisms of China's normalisation with South Korea, General Secretary Jiang refused to meet Kim Il-Sŏng's personal envoy in May 1993 and revoked invitations to North Korean party and military delegations that year (Korea Times 6 June 1993). China's Korea policy experts justified putting economic pressure on North Korea on the grounds that 'those countries that live on aid cannot develop' (Garrett and Glaser 1995: 541). 
While reaffirming the traditional friendship with North Korea (Korea Times 1 November 1994), senior Chinese leaders demonstrated greater enthusiasm for their new found South Korean partners, a country that represented a dynamic model of economic modernisation relevant to China. On his visit to South Korea in November 1994, Premier Li described China's relations with the two Koreas as 'equidistant' and said that China had 'many things to learn from South Korea' (Korea Times 5 November 1994). In his speech to the South Korean national assembly in November 1995, General Secretary (now also President) Jiang implicitly repudiated almost everything North Korea stood for (Korea Times 15 November 1995):

We changed step by step the traditional planned economy into a basic framework of socialist market economy.... With respect to political structure, we have stepped up efforts to strengthen socialist democracy and multi-party cooperation and political consultation under the leadership of the Communist Party.... The reform and opening of the past 17 years are enthusiastically received by the Chinese people as they galvanized China's economic development and brought tangible benefits to the people. The strong collective leadership group of our Party weathered through decades of struggle has successfully achieved the transition from the second generation to the third generation [my italics] 
Despite pressure, the North Korean regime resisted following the Chinese example of faster economic reform after the Soviet bloc collapse. While respecting China's decision to normalise relations with South Korea, Kim Il-Sŏng told the visiting Chinese foreign minister that North Korea would adhere to its own autonomous socialist path and resolve its problems by its own efforts (D.W. News.com 2017). While encouraged by the new Kim Chŏng-Il regime's desperate turn towards light industry, agriculture and trade, China's Korea experts nevertheless viewed the nature of reform to be 'tentative and non-structural' (Garrett and Glaser 1997: 65-7). One even compared North Korea’s plight with China’s Great Leap Forward debacle of 1958-61 ('70 per cent man-made') (Garrett and Glaser 1997: 65). Rather than pursue ambitious economic reform, the new North Korean leadership chose to prioritise resources for 'military-first politics' or sŏn'gun chŏngch'i. Frustrating as this was for China, this policy made sense from the perspective of regime survival. Given the lack of Chinese material incentives for reform, it was logical for the North Korean regime to seek survival by concentrating its limited resources on maintaining the loyalty of the most vital state organisation and social cohort (able-bodied young men). Moreover, as North Korea was still consolidating its hereditary succession, the new regime had to emphasise allegiance to the achievements of the recently departed Kim Il-Sŏng.

North Korea's stubbornness, however, was motivated not only by calculations about regime survival but also by strong ideological convictions. During the Cold War, it had resisted what it regarded as excessive Soviet and Chinese ideological turns (de-Stalinisation, Maoist leftism). In the early post-Cold War period, it was resisting pressure to follow the mono transition strategy of Deng Xiaoping and his successors. From North Korea's perspective, China was betraying a socialist ally. China excused its parsimonious behaviour on the grounds of economic slowdown. Given China's generous material support under much more 
difficult circumstances in the 1960s-70s, the turn towards commercialised trade (not to mention Beijing's normalisation with Seoul) was viewed by the North Korean side as an act of ideological betrayal. Kim Il-Sŏng reportedly denounced China as 'our traitor and enemy' (Zhu 2016: 579). North Korean officials took pride in the survival of 'socialism of our own style' (a slogan associated with Kim Chŏng-Il) while the materially powerful Soviet bloc perished (Oberdorfer 1999: 233). Subsequent official publications attributed the survival from the 'arduous march' (the official euphemism for famine) to 'military-first politics' (Kim 2002: 29-30). In spite of its ideological reluctance, the Kim Chŏng-Il regime was forced by desperation to tolerate grassroots market practices (as China had done before 1978). By late 1997, China was beginning to appreciate these developments. While noting that North Korea's military burden remained too high, official Chinese publications also recognised the tentative economic changes taking place. For example, the Beijing Review (1997: 7) alluded to the trends such as greater priority towards light industry, agriculture and commerce, the strengthening of local autonomy, and introduction of a new ration system that incentivised farmers.

\section{The High Point (c. 2009-12)}

Officially designated as 'China-North Korea Friendship Year', 2009 started badly for bilateral relations with North Korean withdrawal from the Six Party Talks, rocket and nuclear testing. Chinese denunciation and support for UN sanctions, however, soon gave way to diplomatic support and economic engagement. On his landmark visit to North Korea in October 2009, Premier Wen Jiabao promised to boost North Korea's economy and living standards 'by whatever means' (lisuonengji) in order to secure North Korea's return to the 
denuclearisation talks (Qi 2009). Two-way trade reached its highest level under the Kim

Chŏng-Il regime (Figure 1). Diplomatically, China refrained from condemning North Korea outright over the military incidents with South Korea during 2010. This damaged ChinaSouth Korea relations, and prompted closer military cooperation between Seoul and Washington. The new closeness between Beijing and P'yŏngyang was reflected in Kim Chŏng-Il's four visits to China in 2010-11 (May 2010, August 2010, May 2011 and July 2011) towards the end of his life.

\section{The domestic context: emergence of China as a development model}

Apart from the geopolitical considerations, the turn towards economic engagement also needs to be seen against the context of China's emergence as an exemplar of successful systemic transition and national development. As a transition economy, China had proven itself more capable of sustaining high growth rates while implementing gradual (but continuous) market reform compared to the post-socialist states that were once considered more dynamic. In the decade following accession into the World Trade Organisation (2001), China's GDP expanded five-fold (at current prices) compared to six-fold expansion for 1980-2000. China became a middle-income economy whose total GDP surpassed Japan's. In terms of its capacity to finance development cooperation, China emerged as an aid donor rivalling the established OECD donors (Woods 2008). According to China's first White Paper on Foreign Aid, the year 2004 represented a significant turning point in the dispensation of aid (Information Office of the State Council 2011): 
In the 21st century, especially since 2004, on the basis of sustained and rapid economic growth and enhanced overall national strength, China's financial resources for foreign aid have increased rapidly, averaging 29.4 percent from 2004 to 2009 [my italics]

China's rapid rise as a successful developer coincided with the global financial crisis and stagnation of the Western economies from 2008 and bred increasing confidence among Chinese IR scholars and commentators (Lynch 2015). Motivated in part by export markets and raw material access, Chinese aid policy of the late 2000s was not a repeat of the revolutionary aid practices of the 1960s-70s. In contrast with the drive to assimilate neoliberal economic practices during the 1990s, China now represented an alternative model of 'managed globalisation' (Gurtov 2010: 25) capable of harnessing the forces of globalisation for national purpose. Despite its relative poverty, it demonstrated the benefits such an approach could deliver to itself and others (Information Office of the State Council 2011):

However, China remains a developing country with a low per-capita income and a large poverty-stricken population. In spite of this, China has been doing its best to provide foreign aid, to help recipient countries to strengthen their self-development capacity, enrich and improve their peoples' livelihood, and promote their economic growth and social progress. Through foreign aid, China has consolidated friendly relations and economic and trade cooperation with other developing countries, promoted South-South cooperation and contributed to the common development of mankind

While assuming greater global responsibilities, China was adhering firmly to its own political system (Chan 2014: 270-1). In contrast to the Western aid donors' insistence on liberal 
democracy with market economy (Woods 2008), China's aid model was distinguished by its respect for the aid recipient's political system (Information Office of the State Council 2011):

Adhering to equality and mutual benefit, stressing substantial results, and keeping pace with the times without imposing any political conditions on recipient countries, China's foreign aid has emerged as a model with its own characteristics

This changing context coincided with the emergence of encouraging reform signals from P'yŏngyang. China's potential to assist in both North Korea's systemic transition and national development was reflected in Chinese discussions of North Korea during this period.

\section{Effect on policy towards North Korea}

From mid-2009, official Chinese outlets began to carry many optimistic articles about North Korea's readiness for change, especially following Premier Wen's October visit. While western commentators focused on the launch of the anti-market currency redenomination policy in late 2009, Chinese commentators detected positive economic signals coming out of P'yŏngyang. For example, they noted how North Korea's New Year joint editorial (a statement representing the combined views of the newspapers of the ruling KWP, the Korean People's Army and Kim Il-Sŏng Socialist Youth League) of 2010 gave unprecedented emphasis to the development of light industry and agriculture for the improvement of people's livelihoods (Wang 2010). In the same month, the North Korean authorities announced the establishment of Rasŏn as a special city with simplified procedures for foreign investors. The move was likened to China's promotion of special economic zones during the 
1980s (Hu 2010). By mid-2010, the Chinese commentators noted the abandonment of the currency reform and the renewed vitality of the informal market. Emblematic of that vitality was the Chaeha market in Sinŭiju, the largest in North Korea which was compared to midsized general markets in China (Su 2010). These developments indicated that the North Korean regime was now implementing 'reform from above' policies in tandem with spontaneous marketisation 'from below'.

On his visit to China in May 2010, Kim Chŏng-Il agreed to retract previous hard-line positions (including invalidation of the 1953 armistice). North Korea appeared to be responding positively to China's offer to assist reform 'by whatever means'. Chinese visitors were struck by North Korea's similarities to China's early reform period of the 1980s (e.g. existence of rudimentary small businesses, 'two-track' system of basic rations supplemented by market provision, black market for currency exchange). They sensed that North Korea was on the cusp of economic and ideological change (Luo 2010). P'yŏngyang's prevailing slogan of 'feet firmly to the ground, eyes looking outwards to the world' resembled China's slogan of 'opening and reform'. Like China of a generation ago, North Korea was also looking for a peaceful external environment in order to balance reform with stability (Wang 2011). Despite rising inter-Korean tension in 2010, China should continue to act as a neighbour, ally and forerunner of socialist reform (shehui zhuyi gaige de xianxingzhe). In this way, the nuclear crisis would be resolved from its economic roots (cong jingji genyuanshang jiechu chaohe wenti weiji) (Yan 2011).

The death of Kim Chŏng-Il in December 2011 was followed by the rapid conclusion and collapse (i.e. February-April 2012) of the US-North Korea Leap Day Agreement (involving WMD testing moratorium for food aid). Nevertheless, the outlook for China's strategy 
remained positive. In this year of 'strong and prosperous nation' marking the centenary of Kim Il-Sŏng's birth, Kim Chŏng-Ǔn introduced the first major pro-market reforms ('June 28' reforms) for nearly a decade. These reforms were interpreted as fundamental reforms (tixi bianhua) that made the 2002 reforms look like sectoral adjustment (buju diaokong) by comparison. The same source picked up on Kim Chŏng-Ǔn's comment that 'rice is more important than bullets' (Wang 2012). Having prioritized light industry and agriculture over the military sector since 2010, the economic prospects looked positive (providing the external environment remained stable) (Jin 2012):

Since making the transition from the previously prioritised defence sector towards light industry and agriculture, the future trend of the North Korean economy appears positive'

In August 2012, a large North Korean delegation led by Chang Sŏng-T’aek, Kim ChŏngŬn's uncle and reputed number two, visited China to conclude ambitious agreements for the joint development of two special economic zones on the Tumen River border. An editorial in the official China Daily commented very favourably on North Korea's progress and China's contribution to it (China Daily 15 August 2012):

Despite the many security and political incidents that have erupted on the Korean Peninsula in recent years, China-DPRK relations have been growing rapidly.... The growing trade links will provide the DPRK with the commodities and equipment necessary to feed its people and improve the productivity of its industry. But what could be even more valuable is that such cooperation will enable China to offer the DPRK its expertise in managing a transitional economy. China has made remarkable achievements in shaking off poverty and finding a development path that best suits its 
conditions and the DPRK could benefit tremendously from China's experience [my italics]

In response to North Korea's third nuclear test of February 2013, China suspended the ambitious cooperation agreements signed in 2012 and allowed only for-profit transactions. Nevertheless, market dynamics continued to drive up two-way trade (Figure 1). Chinese policy analysts continued to understand the North Korean nuclear problem as a symptom of the post-Cold War imbalance (at North Korea's expense) on the Korean Peninsula. From this perspective, China's role was to boost cooperation with both Koreas and to encourage interKorean relations with the ultimate aim of transcending Cold War divides (Tang 2013). While North Korea's constitutional commitment to nuclear possession (April 2013) was unwelcome, the visit of a North Korean special envoy in May 2013 showed that P'yŏngyang sought to preserve goodwill with Beijing (Wang 2013). Moreover, the parallel economic developments taking place were not lost on Chinese commentators. By the end of 2013, it was noted that the North Korean regime was achieving positive economic results. The designation of several new economic development zones was seen as evidence of North Korea's interest in FDI and trade (Wang 2013). Chinese commentators also picked up on the greater official emphasis on economic development in North Korea's domestic references (Wang 2015). For example, they noted the economic ambitions in Kim Chŏng- Ŭn 's New Year address of 2016 and the close parallels between North Korea's 'our style of economic management' and China's early reforms (Lin and Jin 2016). As the nuclear crisis escalated in 2016-17, the officially-affiliated World Affairs paid less attention to North Korea's ongoing economic transformation and more to the immediate geopolitics. Nevertheless, even at the depth of the crisis in late 2017, Chinese commentators detected signs of rebalancing in favour of economy once more (Zheng 2017). 


\section{North Korea's ordering of priorities}

Chinese economic input (2009-12) could reinforce North Korea's economic reformism up to a point. Selective economic emulation (especially at the local level) (e.g. Reilly 2014a) was not matched by political emulation. The improving economy enabled Kim Chŏng-Ŭn to replace his father's 'military-first politics' with renewed emphasis on the guiding role of the Korean Workers' Party, the institutional basis of his grandfather's rule (Gause 2016: 40-5). However, the style of governance remained unchanged as the institutions continued to function as instruments of the Supreme Leader. While he cultivated a friendly and inclusive style reminiscent of his grandfather (by convening more collective meetings of the formal decision-making bodies), there has been no emergence of collective rule on the post-1976 Chinese pattern. Kim purged many senior leaders. The most significant purge was the execution of Chang Sŏng-T'aek in December 2013. Depicted by many western commentators as the 'regent' behind the young Kim Chŏng-Ǔn, Chang's status as an interlocutor with Beijing could not save his life. Among the charges was the giveaway sale of raw materials to a 'foreign power'. This incident revealed the continuing prioritisation of political consolidation over maintenance of smooth relations with China. The convening of the Seventh Congress of the KWP in May 2016 (the first congress since 1980) was a further sign of consolidation. At the Congress, Kim also assumed the grander title of Party Chairman.

In contrast to China's de-Maoification of the 1980s, there was no relaxation of the Kim family cult in North Korea. The North Korean regime expected prosperity to reinforce monolithic rule rather than to dilute it. The regime promoted the slogan of "civilised country 
with socialism' to coincide with the advance of consumerism. This signalled that improvements in individual prosperity and social consumption (e.g. recreational facilities, housing, education, sporting prowess) would be matched by corresponding devotion to the founding Kim dynasty that made them possible (Lim 2015: 147-54). Beijing gently encouraged P'yŏngyang to modernise its political system. For example, when China voted against a UN General Assembly resolution condemning North Korea's human rights record in December 2015, it clarified that its vote was motivated by support for the principle of national sovereignty. It encouraged North Korea to learn selectively from the West, like China had done, by 'resisting Western pressures, but at the same time absorbing what is useful' (Global Times 18 December 2015). North Korea has adhered resolutely to the monolithic leadership system. With obvious reference of China, Kim Chŏng-Ǔn criticised the 'filthy wind of "reform and openness" blowing in our neighbourhood' in his report to the Seventh Party Congress in May 2016 (Frank 2016). However, the ideological distance has since narrowed. Since the $19^{\text {th }}$ Party Congress of 2017, China has introduced a more personalised and centralised governing style ${ }^{10}$ that is more familiar to North Korea's leaders (who have historically been highly suspicious of liberalising trends emanating from China).

On the nuclear issue, China's economic engagement could not moderate North Korea's nuclear path, a dilemma to which the US held the key. From the geopolitical perspective, Chinese economic input could not remove the security threat that persisted so long as the US denied North Korea's legitimacy as a state. On top of that, it also touched upon deeply-held North Korean sensitivities about national sovereignty. Simply the fact of dependence on China bred resentment from a regime legitimised by resistance to sadaejuŭi (i.e. subordination to big powers) (Eberstadt and Coblin 2014). Stable dependence on China, while boosting prosperity, also had the potential to erode national sovereignty and by 
extension, undermine regime safety (i.e. akin to the influence the US exerted over South Korea during the 1950s-80s). North Korea's co-prioritisation of nuclear defence and economy ('parallel advance') from 2013 (thereby ending the high point of relations) could be understood in the context of these concerns. Sufficient WMD development would provide deterrence and leverage for diplomatic and economic diversification (by luring the US into negotiations) without compromising North Korea's unique political system (the central tenet of chuch'e or national autonomy). 'Parallel advance' placed China in a dilemma between punishing proliferation by economic sanction (its immediate geopolitical interest) and its deeply-held belief in reconstructing North Korea along Chinese lines. The dilemma was eased when North Korea suspended WMD testing at the end of 2017 and made the formal transition from 'parallel advance' to 'economy-first' in April 2018. The point, however, is that P'yŏngyang re-ordered its priorities only after it perceived a favourable bargaining opportunity with the US as a result of developments largely beyond Beijing's direct control (advance of North Korea's nuclear programme, change towards a pro-engagement government in Seoul, positive signals from the Trump administration).

\section{Conclusion}

Accounts based on geopolitical risks and ideational affinity (socialist solidarity and traditional Sino-centric world view) cannot fully explain key turning points in China's North Korea policy in the post-Cold War era. All agree that Beijing seeks P'yŏngyang's acceptance of Chinese reform practices for practical and ideological reasons. From that starting point, we identified two further variables and applied them to explain the low (1992-9) and high points (2009-12) of the relationship in the post-Cold War era. The first variable was China's view of 
the state its own reform path that formed the domestic context of policy towards North Korea. When China's reform model was lagging behind and in need of neo-liberal rejuvenation (early-mid 1990s), North Korea also felt the force of Chinese economic pressure for reform. By contrast, having become a successful development model rivalling liberal capitalism by the late 2000 s, China was more understanding of North Korea's very cautious attitude to reform and offered generous economic inducements. The second variable was North Korea's prioritisation of economic reform versus other objectives (notably WMD development). When North Korea prioritised economic reform, China was economically more supportive. But the ordering of priorities depended upon developments in P'yŏngyang, Washington and Seoul that lay outside of Beijing's direct control. Hence the variables I emphasise may be integrated with the prevailing explanations (stressing geopolitics and ideational affinity) to produce a more comprehensive account of China-North Korea relations.

Geopolitical and ideological motivations mean that China will continuously seek to influence North Korea towards the Chinese political economic path. My discussion reveals the potentials and limitations of that influence. Even when North Korea is well-disposed towards economic reform and assimilation of Chinese practices, it remains totally committed to its own political identity as defined by monolithic rule. When China seeks to induce reform by economic pressure, North Korea perceives this as a direct challenge to its political identity and resists resolutely, forcing China to either relent or induce collapse. When China uses economic incentives to reinforce North Korea's domestic reform impulse, the results are more promising. Nevertheless, China still confronts North Korea's aversion to overdependence on one big power. To avoid over-dependence (and potential subordination), 
North Korea has pursued diplomatic and economic diversification by forceful or peaceful strategies.

Since the beginning of 2018, North Korea has once again been inclined towards diversification by peaceful strategy. This conforms with China's geopolitical interest and objective of transplanting the economic reform model. Since 2018, Chinese commentators are once again bringing up ambitious proposals for economic cooperation. For example, Zhu et al. (2018) mentioned civil nuclear cooperation and joint management of enterprises in the SEZs, two items that appeal to North Korea's quest for sovereignty and development. When he visited P'yŏngyang in June 2019, President Xi not only offered to assist North Korea 'by whatever means' (lisuonengji) but in an allusion to China's wider regional development plans, he also stressed the 'community of common destiny' (mingyun gongtongti) between the two countries (Cao 2019). The mutual defense treaty of 1961 also looks set to be renewed in 2021. These projected developments indicate China's awareness of the potential for North Korea to return to the pursuit of diversification by force if it fails to achieve normalisation with the US. Therefore, it needs to embrace North Korea tightly so as to offset the fallout from failure of diplomacy with the US. At the same time, the embrace cannot be so tight as to threaten the monolithic political regime that is sacrosanct to North Korea. These complex dynamics form the basis of the uneasy yet durable relationship between Beijing and P'yŏngyang.

\section{References}


An, Z. (1990) 'Why does China oppose bourgeois liberalisation?', Beijing Review, 12-18 February: 14-17.

Beijing Review (1997) 'Grain crisis causes hardship for DPRK people’, 40(43): 7.

Cao, S. (24 June 2019) 'Repositioning and promoting China-North Korea relations in the new era' (in Chinese). Accessed at: http://comment.cfisnet.com/2019/0624/1316527.html, 30 June 2019.

Cha, V.D. and Lim, A (2017) New dataset: China-DPRK high level visits since 1953. Accessed at: https://beyondparallel.csis.org/china-dprk-high-level-visits-since-1953/, 10 April 2017.

Chan, G. (2014) 'Capturing China’s international identity: social evolution and its missing links', The Chinese Journal of International Politics, 7(2): 261-81.

China Daily (15 August 2012) 'Editorial: Helping DPRK economy’. Accessed at: http://www.chinadaily.com.cn/opinion/2012-08/15/content_15676584.htm,12 October 2016. D.W. News.com (10 May 2017), 'Qian Qichen's ultra-secret trip to P’yŏngyang' (in Chinese). Accessed at: http://culture.dwnews.com/history/news/2017-05-10/59814490.html, 4 January $\underline{2018 .}$ 
Deng, Y. (27 February 2013) 'China should abandon North Korea', Financial Times.

Accessed at: https://www.ft.com/content/9e2f68b2-7c5c-11e2-99f0-00144feabdc0, 3 March 2013.

Easley, L-E. and Park, Y.I. (2016) 'China’s norms in its near abroad: understanding Beijing's North Korea policy', Journal of Contemporary China, 25(101): 651-68.

Eberstadt, N. (1998) 'North Korea’s interlocked economic crises: some indications from "mirror statistics", Asian Survey, 38(3): 203-30.

Eberstadt, N. and Coblin, A. (2014) 'Dependencia, North Korea Style', Asan Institute Issue Brief, 2014-32.

Frank, R. (20 May 2016) 'The Seventh Party Congress in North Korea: A return to a new normal?', 38 North. Accessed at: http://www.38north.org/2016/05/rfrank052016/, 6 June $\underline{2016 .}$

Fu, Y. (2017) 'The Korean Nuclear Issue: Past Present and Future. A Chinese Perspective'. Accessed at: https://www.brookings.edu/wp-content/uploads/2017/04/north-korean-nuclearissue-fu-ying.pdf, 10 May 2017.

Garrett, B. and Glaser, B. (1997) 'China's pragmatic posture toward the Korean Peninsula', The Korean Journal of Defense Analysis, 9(2): 63-91. 
Garrett, B. and Glaser, B. 'Looking across the Yalu: Chinese assessments of North Korea', Asian Survey, 35(6): 528-45.

Gause, K.E. (2016) 'North Korean political dynamics of the Kim Jong-un era', International Journal of Korean Unification Studies, 25(1): 33-63.

Global Times (20 February 2016) ‘Editorial: US spurs P’yŏngyang’s risky nuclear moves'. Accessed at: http://www.globaltimes.cn/content/969503.shtml, 20 February 2016.

Global Times (18 December 2015) 'Op-ed: China’s N. Korean vote stems from principle’. Accessed at: http://www.globaltimes.cn/content/959322.shtml,18 December 2015.

Gurtov, M. (2010) ‘Changing perspectives and policies', in Dittmer L. and Yu, G.T. (ed.) China, the Developing World, and the New Global Dynamic, Boulder: Lynne Rienner, pp. $13-35$.

Hangyoreh (1 July 2017) 'US steps up pressure on China by designating Dandong bank a money laundering concern'. Accessed at: http://english.hani.co.kr/arti/english_edition/e international/801043.html, 3 July 2017. Hu, M. (2010) 'North Korean launches economic adjustment measures, World Affairs, No. 7 (in Chinese). Accessed at: http://mall.cnki.net/magazine/Article/SJZS201007011.htm, 8 October 2016. 
Information Office of the State Council (22 April 2011) White Paper on Foreign Aid. Accessed at:

http://english.gov.cn/archive/white_paper/2014/09/09/content_281474986284620.htm, 9

December 2016.

Isozaki, A. (2017) Understanding the North Korean Regime, Washington DC: Wilson Centre.

Jia, Q. (29 August 2016) 'Our three major misunderstandings regarding North Korea', Charhar Institute (in Chinese). Accessed at:

http://www.charhar.org.cn/newsinfo.aspx?newsid=10998, 3 September 2016.

Jia, Q. (7 September 2017) 'The folly of North Korea's sixth nuclear test', CRNTT (in Chinese). Accessed at: http://hk.crntt.com/crn-

webapp $/ \mathrm{mag} /$ docDetail.jsp?coluid=0\&docid=104803863\&page=5, 10 September 2017.

Jiang, Z. (1991) 'Building socialism the Chinese way', Beijing Review, 8-14 July: 14-31.

Jin, M. (2012) 'North Korean economy: can it open the gate to power and prosperity?', World Affairs, No. 12 (in Chinese). Accessed at:

http://mall.cnki.net/magazine/Article/SJZS201212013.htm, 12 October 2016.

Kim, C.U. (2002) Songun Politics of Kim Jong Il, Pyongyang: Foreign Languages Publishing House. 
Kim, H. (2010) 'From a buffer zone to a strategic burden: evolving Sino-North Korea relations during the Hu Jintao era', The Korean Journal of Defense Analysis, 22(1): 57-74

Kim, S. (2001) 'The making of China's Korea's policy in the era of reform', in Lampton, D.M. (ed.) The Making of Chinese Foreign and Security Policy in the Era of Reform, 19782000, Stanford: Stanford University Press, pp. 371-408.

Kim, S-C. (2010) 'North Korea's relationship with China: from alignment to active independence', in Lam, P.E., Narayanan, G. and Dürkop, C. (ed.) East Asia 's Relations with a Rising China, Berlin: Konrad Adenauer Stiftung, pp. 102-42.

Klein, K. (2010) “"New authoritarianism” in China: political reform in the one-party state', Telos, 151: 1-27.

Korea Times (15 November 1995) 'China opposes hegemony, power politics'.

Korea Times (2 November 1994) 'China tries to give equal affection to both Koreas'.

Korea Times (13 October 1991) 'Editorial: Kim Il-Sung's China visit'.

Korea Times (6 June 1993) 'Jiang Zemin refuses to meet Kim Il-Sung’s envoy: Jingbao'.

Korea Times (8 October 1991) 'Kim Il-Sung only gets lecture for reforms'. 
Korea Times (5 November 1994) 'Li Peng hints at replacing armistice agreement: 4 parties should work out peace accord'.

Korea Times (6 October 1991) 'Li lectures Kim on merit of market economy'

Lee, C-J. (1996) China and Korea: Dynamic Relations, Stanford: Hoover Institution Press.

Li, H. (2015) Political Thought and China's Transformation: Ideas Shaping Reform in PostMao China, Basingstoke: Palgrave-Macmillan.

Li, P. (1991) ‘Quicken structural economic reform’, Beijing Review, 17-23 June: 11-15.

Lin, J. and Jin, M. (16 February 2016) 'The reasons for the positive turn in the North Korean economy under Kim Chŏng-Ǔn and its trend', Centre for Marxist Parties in Foreign Countries of CCNU (in Chinese). Accessed at: http://www.ccnumpfc.com/index.php/View/147.html, 1 March 2016.

Lin, J.Y. (1995) 'Can China’s “mini bang” succeed?', Contemporary Economic Policy, 13(1): 10-14.

Lim, E-C. (2015) 'The goal and the current status of building a "civilised country with socialism" at the $70^{\text {th }}$ anniversary of the foundation of the party', in Korea Development Institute (KDI) School of Public Management (ed.), 2016 DPRK Country Report, Seoul: KDI School, pp. 145-75. 
Luo, J. (2010) 'Visit to North Korea', World Affairs, (in Chinese). Accessed at:

http://mall.cnki.net/magazine/Article/SJZS201019016.htm, 8 October 2016.

Lynch, D.C. (2015) China's Futures: PRC Elites Debate Economics, Politics, and Foreign Policy, Stanford: Stanford University Press.

Ministry of Foreign Affairs (22 September 2009) 'Press conference with MOFA spokesperson Jiang Yu'. Accessed at:

http://english.mofcom.gov.cn/article/services/supplydemandofchina/cooperation/200909/200 90906538666.shtml, 27 September 2009.

Noesselt, N. (2014) 'China’s contradictory role(s) in world politics: decrypting China's North Korea strategy', Third World Quarterly, 35(7): 1307-25.

Oberdorfer, D. (1999) The Two Koreas: A Contemporary History, New York: Basic Books.

Qi, H. (2009) 'Meaning of Wen Jiabao's visit to North Korea', World Affairs, No. 20 (in Chinese). Accessed at: http://mall.cnki.net/magazine/Article/SJZS200920016.htm, 5 October $\underline{2016 .}$

Reilly, J. (2014a) 'China's market influence in North Korea', Asian Survey, 54(5): 894-917.

Reilly, J. (2014b) 'The curious case of China's aid to North Korea', Asian Survey, 54(6): $1158-1183$. 
Sautman, B. (1992) 'Sirens of the strongman: neo-authoritarianism in recent Chinese political theory', The China Quarterly, 129: 72-102.

Shen, Z. (19 March 2017) 'North Korea is China’s latent enemy'. Lecture at Dalian Foreign Languages University (in Chinese). Accessed at: http://zhanlve.org/?p=774, 10 July 2017.

Shen, Z. and Xia, Y. (2015) 'Refuting two historical myths: a new interpretation of ChinaNorth Korean relations', Freeman, Carla P., China and North Korea: Strategic and Policy Perspectives from a Changing China, New York, Palgrave Macmillan, pp.91-106.

Shi, Y. (2015) 'Painful lessons, reversing practices, and ongoing limitations: China facing North Korea since 2003', in Freeman, Carla P., China and North Korea: Strategic and Policy Perspectives from a Changing China, New York, Palgrave Macmillan, pp. 18-36.

So, A. and Chu Y-W. (2012) 'The transition from neoliberalism to state neoliberalism in China at the turn of the twenty-first century', in Chang, K-S., Fine, B. and Weiss, L. (ed.), Developmental Politics in Transition: The Neoliberal era and Beyond, Basingstoke: Palgrave-Macmillan, pp. 166-87.

Su, J. (2010) 'North Korea on the verge of a new era?', World Affairs, No. 20 (in Chinese). Accessed at: http://mall.cnki.net/magazine/Article/SJZS201020005.htm, 8 October 2016.

Tang, Y. (2013) 'Accurately understanding China's strategic interest on the Korean Peninsula', World Affairs, No. 6 (in Chinese). Accessed at: http://mall.cnki.net/magazine/Article/SJZS201306035.htm, 14 October 2016. 
Wang, M. (2013) 'A quiet end to 2013 for the Korean Peninsula but 2014 may be more lively', World Affairs, No. 24 (in Chinese). Accessed at:

http://mall.cnki.net/magazine/Article/SJZS201324036.htm, 14 October 2016.

Wang, M. (2013) 'Difficult for the Korean Peninsula to put aside the bleak situation', World Affairs, No. 12 (in Chinese). Accessed at:

http://mall.cnki.net/magazine/Article/SJZS201312030.htm, 14 October 2016.

Wang, M. (2011) 'Give North Korea a degree of support', World Affairs, No. 2 (in Chinese). Accessed at: http://mall.cnki.net/magazine/Article/SJZS201102024.htm, 10 October 2016.

Wang, M. (2012) 'North Korea, progress and innovation amid change', World Affairs, No. 16 (in Chinese). Accessed at: http://mall.cnki.net/magazine/Article/SJZS201216036.htm, 12 October 2016.

Wang, M. (2010) 'North Korea's currency reform and tasks for the new year', World Affairs, No. 2 (in Chinese). Accessed at: http://mall.cnki.net/magazine/Article/SJZS201002010.htm, $\underline{8 \text { October } 2016 .}$

Wang, M. (2015) ‘Seek major stability, don’t disregard small changes: factors influencing stability on the Korean Peninsula 2016, World Affairs, No. 24 (in Chinese). Accessed at: http://mall.cnki.net/magazine/Article/SJZS201524040.htm, 18 October 2016. 
Woods, N. (2008) 'Whose aid? Whose influence? China, emerging donors and the silent revolution in development assistance', International Affairs, 84(6): 1205-1221.

World Affairs Editorial Office. Accessed at: http://sjzs.qikann.com/cssci/introduce/, 1 October 2016.

Wu, J. (2009) 'China's transition to a market economy: how far across the river?', in Ichimura, S., Sato, T. and James, W. (ed.) Transition from Socialist to Market Economies: Comparison of European and Asian Experiences, Basingstoke: Palgrave-Macmillan, pp. 3766.

Wu, X. (2018) 'Cooperation, competition and shaping the outlook: the US and China's neighbourhood diplomacy', International Affairs, 92(4): 849-67.

Yan, Y. (2011) 'Following the positive turn in North Korea's economic situation, adjustment of China's diplomatic policy, change in the condition of the Korean peninsula, China quietly changes the form of its aid to North Korea', World Affairs No. 16 (in Chinese). Accessed at: http://mall.cnki.net/magazine/Article/SJZS201116009.htm, 10 October 2016.

Zeng, J., Xiao Y. and Breslin, S. (2015) 'Securing China's core interests: the state of the debate in China', International Affairs, 91(2): 245-266.

Zhang, L. (2009) 'Korea 2009: the crossroads of success and failure', World Affairs, No. 22 (in Chinese). Accessed at: http://mall.cnki.net/magazine/Article/SJZS200922017.htm, 5 October 2016. 
Zhang, L. (2011) 'Kim Chŏng-Il visits China three times in a year: major strategic diplomacy initiative from North Korea', World Affairs, No. 11 (in Chinese). Accessed at: http://mall.cnki.net/magazine/Article/SJZS201112017.htm, 10 October 2016.

Zheng, J. (2017) 'What does the second plenum of the seventh central committee of the KWP reveal?', World Affairs, No. 21 (in Chinese). Accessed at:

http://mall.cnki.net/magazine/magadetail/SJZS201721.htm, 10 December 2017.

Zhu, F. and Beauchamp-Mustafaga, N. (2015) 'North Korea's security implications for China', in Freeman, C.P. (ed.) China and North Korea: Strategic and Policy Perspectives from a Changing China, New York: Palgrave Macmillan, pp. 37-64.

Zhu, F., Yue, L. and Qin, K. (29 May 2018) '’North Korea's present economic situation, trends, main economic problems and thoughts on appropriate measures', Development Research Centre of the State Council, (in Chinese). Accessed at: http://www.chinathinktanks.org.cn/content/detail/id/lgd2ne99, 15 March 2019.

Zhu, Z. (2016) 'Comrades in broken arms: shifting Chinese policies toward North Korea', Asian Politics \& Policy, 8(4): 575-92. 


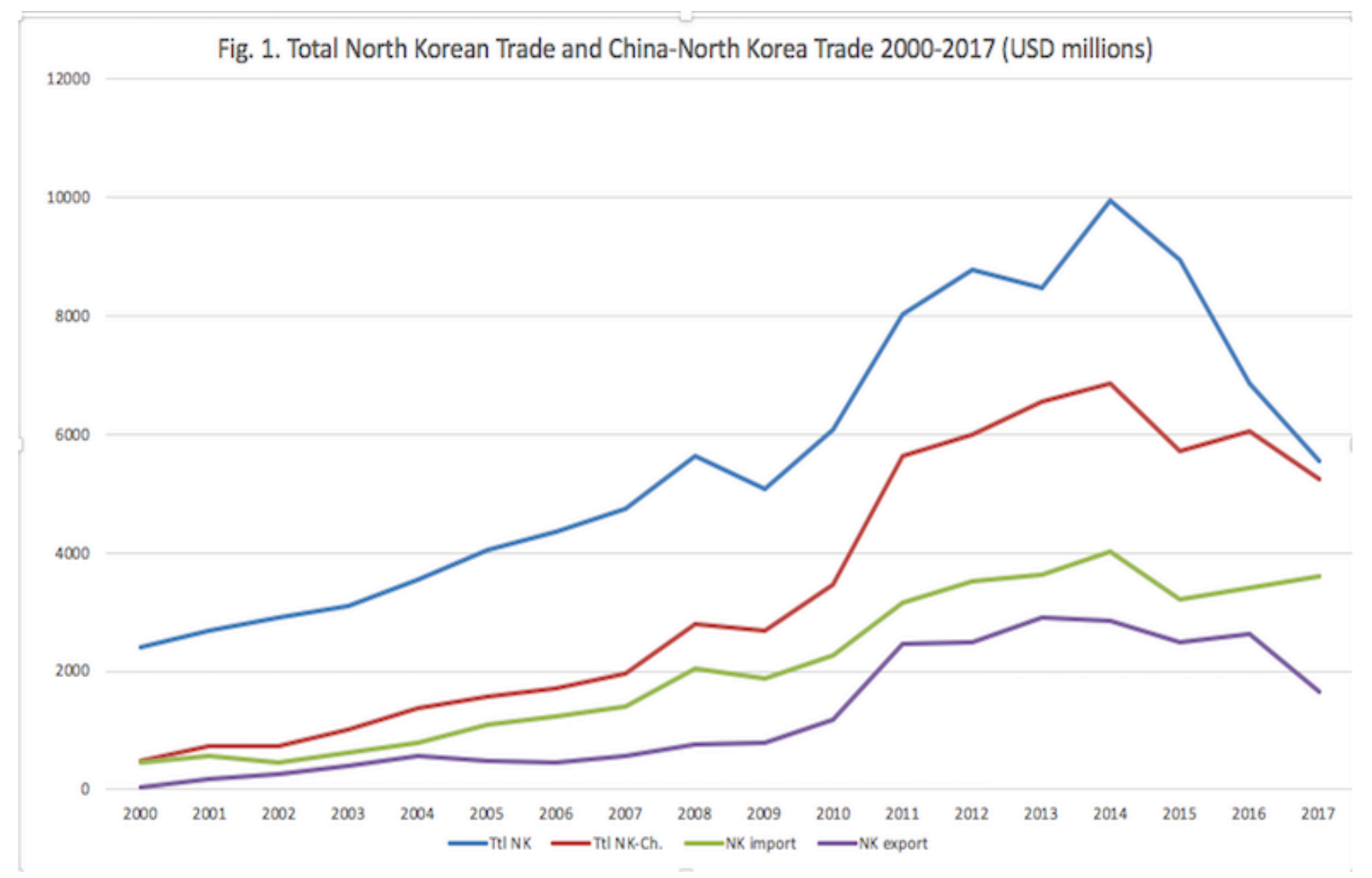

Source: National Statistics Office: Major Indicators of North Korean Economy, Seoul: NSO, several issues. 


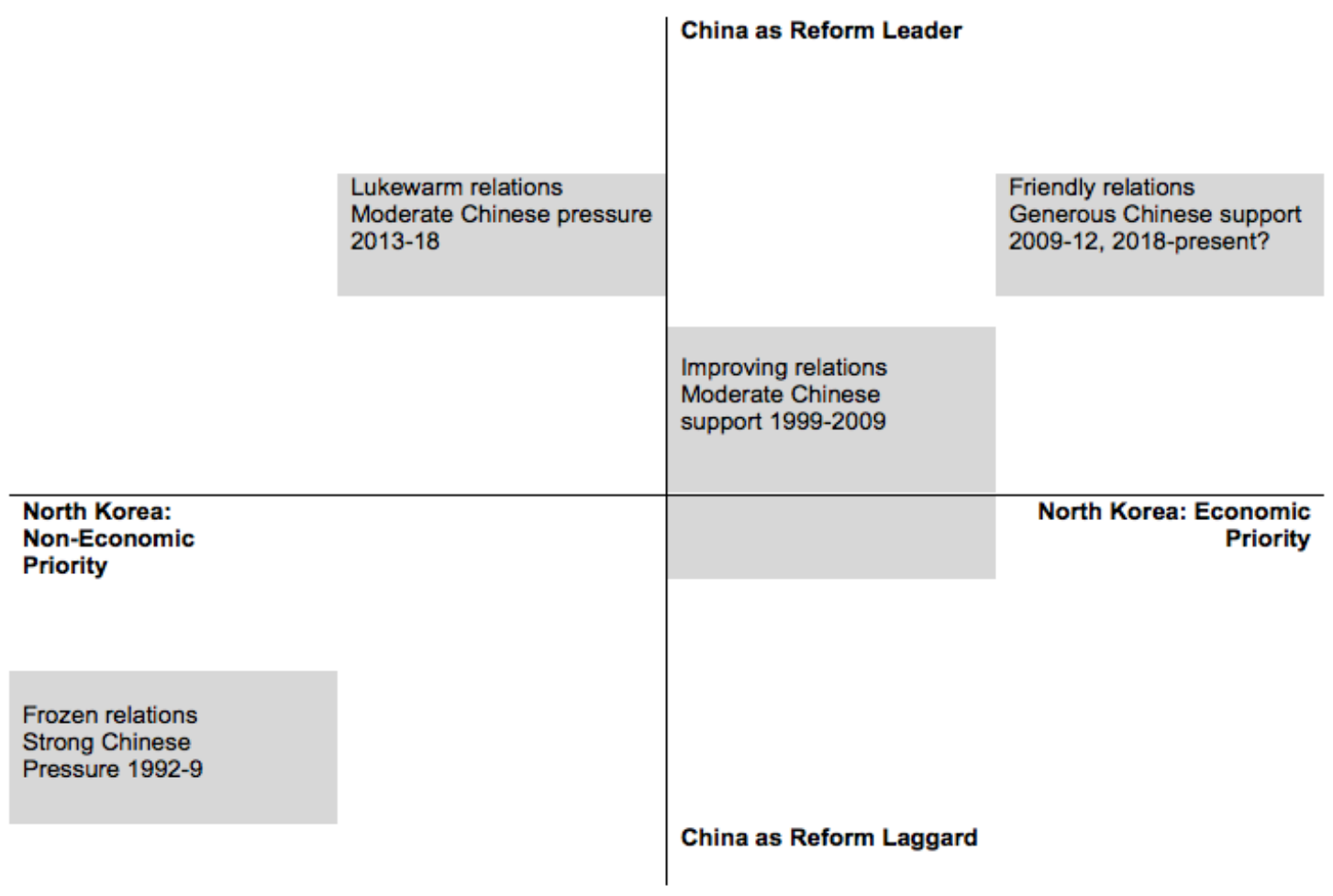

${ }^{1}$ Research for this article was supported by the Academy of Korean Studies Grant AKS2015-R21. I would like to thank Rosemary Foot and Lawrence Whitehead and the anonymous reviewers for their feedback on previous drafts as well as the editorial team of The Pacific Review for its administrative support.

${ }^{2}$ Here understood as nuclear weapons and the means for their delivery.

${ }^{3}$ As of September 2017, this development consisted of six nuclear tests $(2006,2009,2013$, 2016-twice, 2017), five missile tests under leader Kim Chŏng-Il (1994-2011) and 25 missile tests (20 in 2016-2017) under Kim Chŏng-Ǔn (2012-present).

4 'China' refers to the authoritative decisions of the Politburo Standing Committee based on the advice of the Foreign Affairs Leading Small Group and expressed via official outlets. 
${ }^{5}$ North Korea is subject to sanctions under eight UNSC Resolutions: 1718 (2006); 1874 (2009); 2087 (2013); 2094 (2013); 2270 (2016); 2321 (2016); 2371 and 2375 (2017). Under 2375 , annual export of oil was capped at 500,000 tons.

${ }^{6}$ Held in Beijing, the talks comprise the two Koreas, China, US, Russia and Japan. Six rounds of talks occurred between 2003 and 2008. They produced two abortive denuclearisation roadmaps (19 September 2005 and 13 February 2007).

${ }^{7}$ In the state-to-state capacity, Vice President Li Yuanchao visited on the $60^{\text {th }}$ anniversary of the Korean War armistice agreement in July 2013. At the party-to-party level, Politburo Standing Committee member Liu Yunshan (ranked fifth in the leadership) visited on the $70^{\text {th }}$ anniversary of the founding of the Korean Workers' Party (KWP) in October 2015. KWP Vice Chairman Ri Su-Yŏng visited Beijing in June 2016 to brief President Xi on the Seventh Congress of the KWP (6-9 May 2016).

${ }^{8}$ Two-way trade between China and South Korea was USD 221 billions in 2015 compared with USD 5.7 billion with North Korea.

${ }^{9}$ This refers to meetings between General Secretaries or between a General Secretary and a Head of State (Chinese President or Chair of the North Korean Supreme People's Assembly). ${ }^{10}$ The two-term limitation on the tenure of the General Secretary was removed and ' $\mathrm{Xi}$ Jinping Thought' was officially written into the party constitution as guiding ideology. This was accompanied by enhanced emphasis on party supervision of society and discipline within the party-state (represented by the formation of a National Supervisory Commission in 2018). 